\title{
Stability of Supercooled Liquid and Transformation Behavior in Zr-Based Glassy Alloys
}

\author{
Junji Saida ${ }^{1}$ * , Mitsuhide Matsushita ${ }^{2}$ and Akihisa Inoue $^{3}$ \\ ${ }^{1}$ Inoue Superliquid Glass Project, ERATO, Japan Science and Technology Corporation (JST), Sendai 982-0807, Japan \\ ${ }^{2}$ JEOL Ltd., Akishima, Tokyo 196-8558, Japan \\ ${ }^{3}$ Institute for Materials Research, Tohoku University, Sendai 980-8577, Japan
}

\begin{abstract}
We investigated the stability of the supercooled liquid in Zr-based glassy alloys by examination of their transformation behavior. The primary phase is an fcc $\mathrm{Zr}_{2} \mathrm{Ni}$ phase in a $\mathrm{Zr}_{65} \mathrm{Al}_{7.5} \mathrm{Ni}_{10} \mathrm{Cu}_{17.5}$ glassy alloy with high glass-forming ability (GFA). By substitution of $\mathrm{Ag}, \mathrm{Pd}$, $\mathrm{Au}$ or Pt for only $1 \mathrm{at} \% \mathrm{Cu}$, an icosahedral quasicrystalline phase (I-phase) precipitates with the $\mathrm{fcc}_{\mathrm{Zr}} \mathrm{Ni}$ phase. The primary phase changes to the single I-phase at higher noble metal contents. It is further found that the I-phase precipitates by a small amount of substitution for $\mathrm{Cu}$ with other elements as well as the noble metals, which have a weak or positive chemical affinity with one of the constitutional elements in the $\mathrm{Zr}-\mathrm{Al}-\mathrm{Ni}-\mathrm{Cu}$ glassy alloy. Thus, the slight deviation from the three component rules for high GFA is effective for the I-phase formation. The I-phase is also formed as a primary phase in the $\mathrm{Zr}_{65+y} \mathrm{Al}_{7.5} \mathrm{Ni}_{10} \mathrm{Cu}_{17.5-y}(y=1-7)$ glassy alloys. A slight change in the composition has the similar effect as the addition of element such as noble metals and so on. An icosahedron is contained as a structure unit in the fcc $\mathrm{Zr}_{2} \mathrm{Ni}$ and I-phases and hence the glassy structure is correlated with the local icosahedral atomic configuration. The high-resolution transmission electron microscopy image of the $\mathrm{Zr}_{70} \mathrm{Al}_{7.5} \mathrm{Ni}_{10} \mathrm{Cu}_{12.5}$ glassy alloy reveals a possibility of the existence of the icosahedral ordered regions. It is therefore, concluded that the icosahedral short- or medium-range order exists in the supercooled liquid as well as in the glassy phase and it stabilizes the supercooled liquid state in the Zr-based alloys. An I-phase also precipitates as a primary phase by substituting Pd, Au or Pt for only 1 at $\% \mathrm{Cu}$ in the $\mathrm{Zr}_{70} \mathrm{Cu}_{30}$ glassy alloy. From these results, the appearance of the supercooled liquid region is attributed to the existence of the icosahedral atomic configuration consisting of $\mathrm{Zr}$ and $\mathrm{Cu}$.
\end{abstract}

(Received February 7, 2002; Accepted March 19, 2002)

Keywords: zirconium-based glassy alloy, icosahedral phase, transformation, supercooled liquid state, metastable phase

\section{Introduction}

Recent discoveries of a number of bulk glassy alloys with high GFA in Zr-based multicomponent alloy systems ${ }^{1-3)}$ have attracted much attention in the aspects of scientific interests in a high stability of glassy state as well as industrial applications. ${ }^{4)}$ Among $\mathrm{Zr}-\mathrm{Al}-\mathrm{TM}$ ( $\mathrm{TM}=$ transition metals) alloy systems, the $\mathrm{Zr}_{65} \mathrm{Al}_{7.5} \mathrm{Ni}_{10} \mathrm{Cu}_{17.5}$ glassy alloy has an extremely high GFA as is evidenced by the largest value of the supercooled liquid region which is defined as the temperature interval between glass transition temperature, $T_{\mathrm{g}}$ and crystallization temperature, $T_{\mathrm{x}}{ }^{5}{ }^{5}$ The stable supercooled liquid state contributes to the production of bulk glassy alloy. It is suggested that the stability of the supercooled liquid state is strongly correlated with their local structure. ${ }^{6,7)}$ Very recently, the precipitation of an I-phase was reported in the $\mathrm{Zr}_{65} \mathrm{Al}_{7.5} \mathrm{Ni}_{10} \mathrm{Cu}_{17.5}$ glassy alloy by addition of 5 to 10 at $\%$ noble metal substituted for the $\mathrm{Cu}$ element. ${ }^{8-10)}$ The I-phase has a fine grain size in the diameter less than approximately $50 \mathrm{~nm}$, which exhibits a high nucleation rate. The authors have reported the I-phase formation by addition of other elements such as $\mathrm{V}, \mathrm{Nb}$, Ta and Mo, which have positive or nearly zero mixing enthalpies against major constituent elements in the $\mathrm{Zr}-\mathrm{Al}-\mathrm{Ni}-\mathrm{Cu}$ alloy. ${ }^{11,12)}$ It is interpreted that the I-phase can be formed by deviating the three component rules for high GFA in the Zr-based multicomponent alloy, which are described as: (1) multicomponent systems consisting of more than three elements; (2) significant difference in atomic size ratios above about $12 \%$ among the three main constituent elements; and (3) negative heats of mixing among the three

*Corresponding author: E-mail address: jsaida@sendai.jst.go.jp main constituent elements. ${ }^{13)}$ These discoveries also imply the correlation between the local icosahedral order and the high thermal stability of supercooled liquid state. ${ }^{14)}$ In the recent studies, ${ }^{15)}$ it was revealed that ordered regions exist in the glassy state of the $\mathrm{Zr}_{54.5} \mathrm{Ti}_{7.5} \mathrm{Cu}_{20} \mathrm{Ni}_{8} \mathrm{Al}_{10}$ multicomponent alloy. However, the ordered regions were too small to identify their structure.

In this paper, we investigate the stability of the supercooled liquid state in $\mathrm{Zr}-\mathrm{Al}-\mathrm{Ni}-\mathrm{Cu}$ glassy alloys by the detailed examination of the transformation behavior. Especially, we have focused on the structure of the primary phase, which reflects the local structure in the glassy or supercooled liquid state. From these studies, we intend to clarify the dominant factor for high GFA and high stability of supercooled liquid state in the Zr-based glassy alloy.

\section{Experimental Procedure}

Melt-spun $\mathrm{Zr}_{65+y} \mathrm{Al}_{7.5} \mathrm{Ni}_{10} \mathrm{Cu}_{17.5-y}(y=0$ to 9) alloys with a cross section of $0.03 \times 1 \mathrm{~mm}^{2}$ were produced from alloy ingots prepared by arc melting high-purity metals of 99.9 mass $\% \mathrm{Zr}, 99.999$ mass $\% \mathrm{Al}, 99.9$ mass $\% \mathrm{Ni}$ and 99.999 mass\%Cu. The alloy ribbons substituting $\mathrm{Ag}, \mathrm{Pd}$, $\mathrm{Au}$ or $\mathrm{Pt}$ for 1 to 4 at\% $\mathrm{Cu}$ in the $\mathrm{Zr}_{65} \mathrm{Al}_{7.5} \mathrm{Ni}_{10} \mathrm{Cu}_{17.5}$ alloy were also prepared. The alloy compositions represent nominal atomic percentages and the sample preparation was carried out in a purified argon atmosphere. Thermal properties were measured by differential scanning calorimetry (DSC) at a heating rate of $0.67 \mathrm{Ks}^{-1}$. The samples were annealed in the DSC cell in an argon atmosphere at a heating rate of $1.67 \mathrm{Ks}^{-1}$. The annealed structure was examined by $\mathrm{X}$ - 
ray diffractometry with $\mathrm{Cu}-\mathrm{K} \alpha$ radiation and field-emission transmission electron microscopy (FE-TEM) with an accelerating voltage of $300 \mathrm{kV}$ (JEOL JEM-3000F). The sample for TEM observation was prepared by the ion milling technique. The compositional analysis was performed by nanobeam energy dispersive X-ray spectroscopy (EDX) with a beam diameter of approximately $5 \mathrm{~nm}$. The observation of an ordered region was performed for the as-spun $\mathrm{Zr}_{70} \mathrm{Al}_{7.5} \mathrm{Ni}_{10} \mathrm{Cu}_{12.5}$ alloy using a high-resolution transmission electron microscope (HREM). The sample for HREM was cooled with liquid nitrogen during ion milling. The oxygen content of the as-quenched ribbon samples was analyzed to be less than 800 mass ppm by inductively coupled plasma spectroscopy, where the influence of oxygen impurity on the transformation behavior can be disregarded. ${ }^{16)}$

\section{Results}

3.1 Change in transformation behavior by addition of noble metal

Figure 1 shows DSC curves of the melt-spun $\mathrm{Zr}_{65} \mathrm{Al}_{7.5} \mathrm{Ni}_{10^{-}}$ $\mathrm{Cu}_{17.5}$ and $\mathrm{Zr}_{65} \mathrm{Al}_{7.5} \mathrm{Ni}_{10} \mathrm{Cu}_{16.5}$ ( $\mathrm{Ag}, \mathrm{Pd}, \mathrm{Au}$ and $\left.\mathrm{Pt}\right)_{1}$ glassy alloys. All of the curves clearly indicate the glass transition, followed by a large supercooled liquid region. The glass transition temperatures, $T_{\mathrm{g}}$ are nearly the same among the alloys. A sharp single exothermic peak is observed as a main crystallization reaction in the $\mathrm{Zr}_{65} \mathrm{Al}_{7.5} \mathrm{Ni}_{10} \mathrm{Cu}_{17.5}$ glassy alloy. By substituting $\mathrm{Ag}, \mathrm{Pd}, \mathrm{Au}$ or $\mathrm{Pt}$ for only $1 \mathrm{at} \% \mathrm{Cu}$, the main exothermic peak becomes broader. The crystallization temperatures in the noble metal-containing alloys are in range of

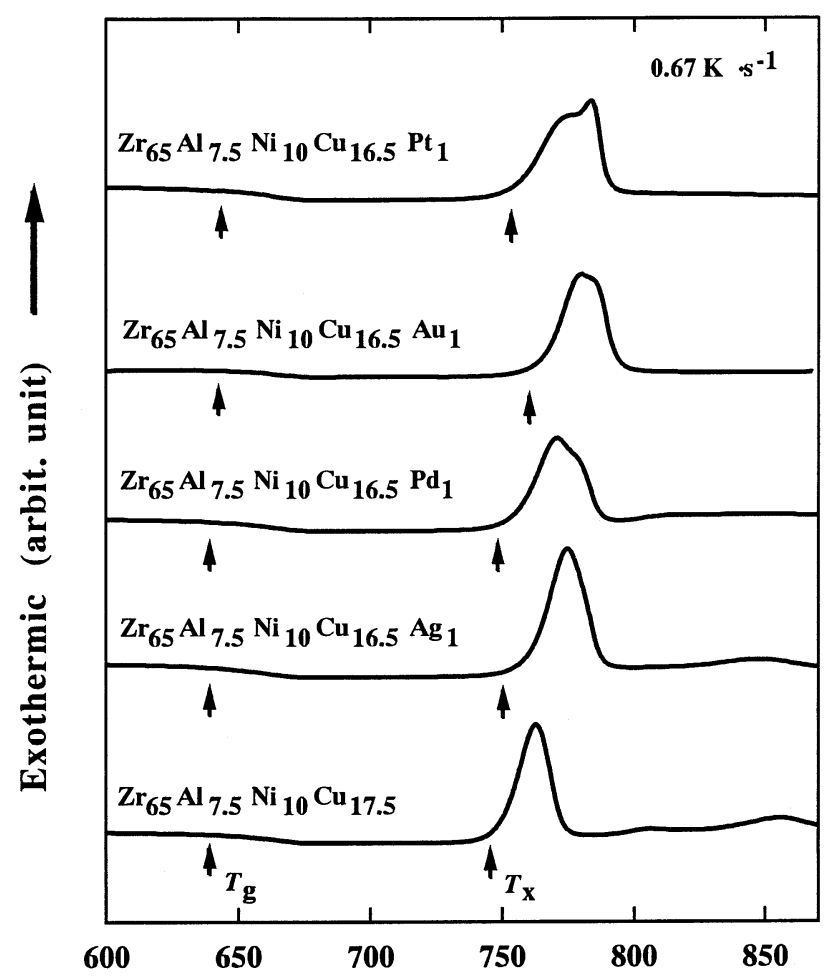

Temperature, $\boldsymbol{T} / \mathbf{K}$

Fig. 1 DSC curves of melt-spun $\mathrm{Zr}_{65} \mathrm{Al}_{7.5} \mathrm{Ni}_{10} \mathrm{Cu}_{17.5}$ and $\mathrm{Zr}_{65} \mathrm{Al}_{7.5} \mathrm{Ni}_{10} \mathrm{Cu}_{16.5}(\mathrm{Ag}, \mathrm{Pd}, \mathrm{Au} \text { and } \mathrm{Pt})_{1}$ glassy alloys.
747 to $753 \mathrm{~K}$, which are slightly higher than that $(744 \mathrm{~K})$ in the $\mathrm{Zr}_{65} \mathrm{Al}_{7.5} \mathrm{Ni}_{10} \mathrm{Cu}_{17.5}$ alloy. In order to examine the primary phase in these samples, annealing was performed at a temperature near $T_{\mathrm{x}}$. The X-ray diffraction (XRD) patterns of the $\mathrm{Zr}_{65} \mathrm{Al}_{7.5} \mathrm{Ni}_{10} \mathrm{Cu}_{16.5}(\mathrm{Ag}, \mathrm{Pd}, \mathrm{Au} \text { and } \mathrm{Pt})_{1}$ glassy alloys annealed for $30 \mathrm{~s}$ at the temperatures of 750 and $755 \mathrm{~K}$ are shown in Fig. 2. The XRD pattern of the $\mathrm{Zr}_{65} \mathrm{Al}_{7.5} \mathrm{Ni}_{10} \mathrm{Cu}_{17.5}$ glassy alloy annealed for $30 \mathrm{~s}$ at $740 \mathrm{~K}$ is also shown for comparison in the figure. Some sharp diffraction peaks are observed in addition to a halo peak corresponding to the residual glassy phase for all the samples. In the $\mathrm{Zr}_{65} \mathrm{Al}_{7.5} \mathrm{Ni}_{10} \mathrm{Cu}_{17.5}$ glassy alloy, the primary crystalline phase is identified as a single fcc $\mathrm{Zr}_{2} \mathrm{Ni}$ with a large lattice parameter of $a=$ $1.227 \mathrm{~nm} .{ }^{17)}$ In the $\mathrm{Zr}_{65} \mathrm{Al}_{7.5} \mathrm{Ni}_{10} \mathrm{Cu}_{16.5}(\mathrm{Ag}, \mathrm{Pd}, \mathrm{Au} \text { and } \mathrm{Pt})_{1}$ glassy alloys, the diffraction peaks recognized as an I-phase are observed in addition to the fcc $\mathrm{Zr}_{2} \mathrm{Ni}$ phase.

For further identification of the microstructure of the primary phase, TEM observation was performed. The bright-field TEM images ((a) and (c)) and selected-area electron diffraction patterns (SADP) ((b) and (d)) of the $\mathrm{Zr}_{65} \mathrm{Al}_{7.5} \mathrm{Ni}_{10} \mathrm{Cu}_{16.5} \mathrm{Pd}_{1}$ glassy alloy annealed for $30 \mathrm{~s}$ at $750 \mathrm{~K}$ are shown in Fig. 3. Two types of particles are observed in Figs. 3(a) and (c). The particles in Fig. 3(a) have a dendrite structure in the diameter range of 200 to $1000 \mathrm{~nm}$ in the glassy matrix. The SADP taken from the precipitated particles shown in Fig. 3(b) clearly indicates the quasiperiodic twofold axis, which is identified as an I-phase. In contrast, nearly cuboid particles in the diameter of approximately $500 \mathrm{~nm}$ are also observed in the glassy matrix in Fig. 3(c), of which SADP is characterized as the fcc $\mathrm{Zr}_{2} \mathrm{Ni}$ phase

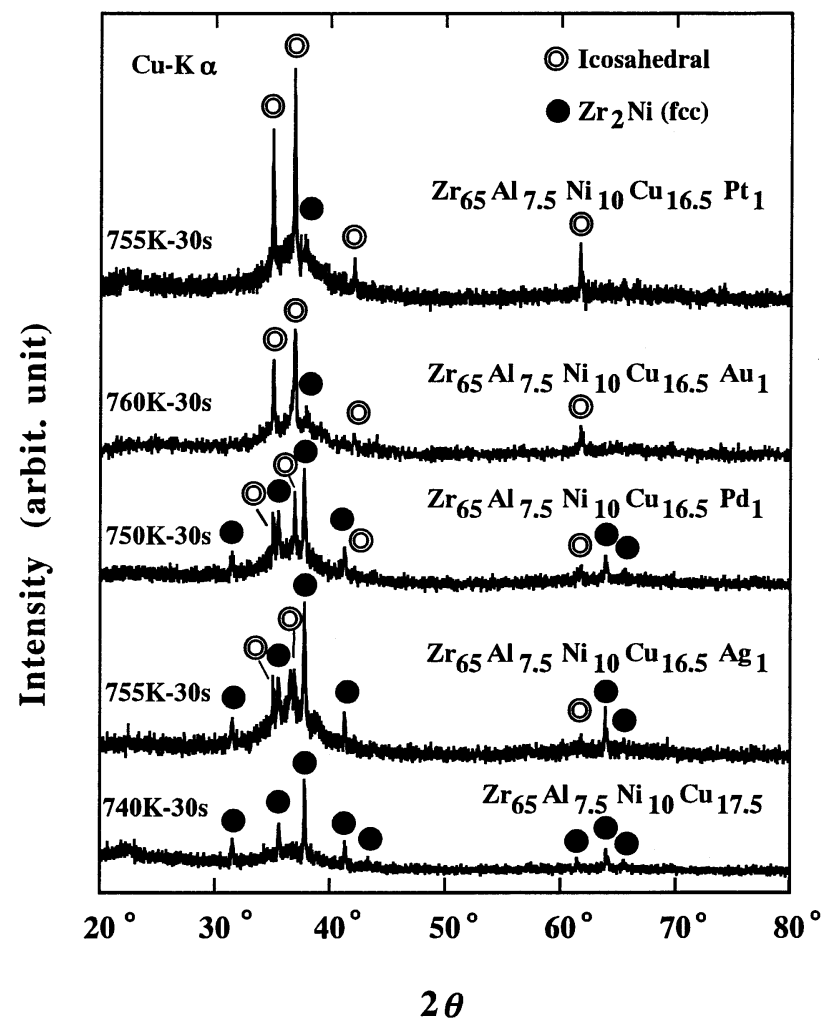

Fig. 2 X-ray diffraction patterns of the $\mathrm{Zr}_{65} \mathrm{Al}_{7.5} \mathrm{Ni}_{10} \mathrm{Cu}_{17.5}$ and $\mathrm{Zr}_{65} \mathrm{Al}_{7.5} \mathrm{Ni}_{10} \mathrm{Cu}_{16.5}(\mathrm{Ag}, \mathrm{Pd}, \mathrm{Au} \text { and } \mathrm{Pt})_{1}$ glassy alloys annealed for $30 \mathrm{~s}$ in a temperature range of 740 to $755 \mathrm{~K}$. 


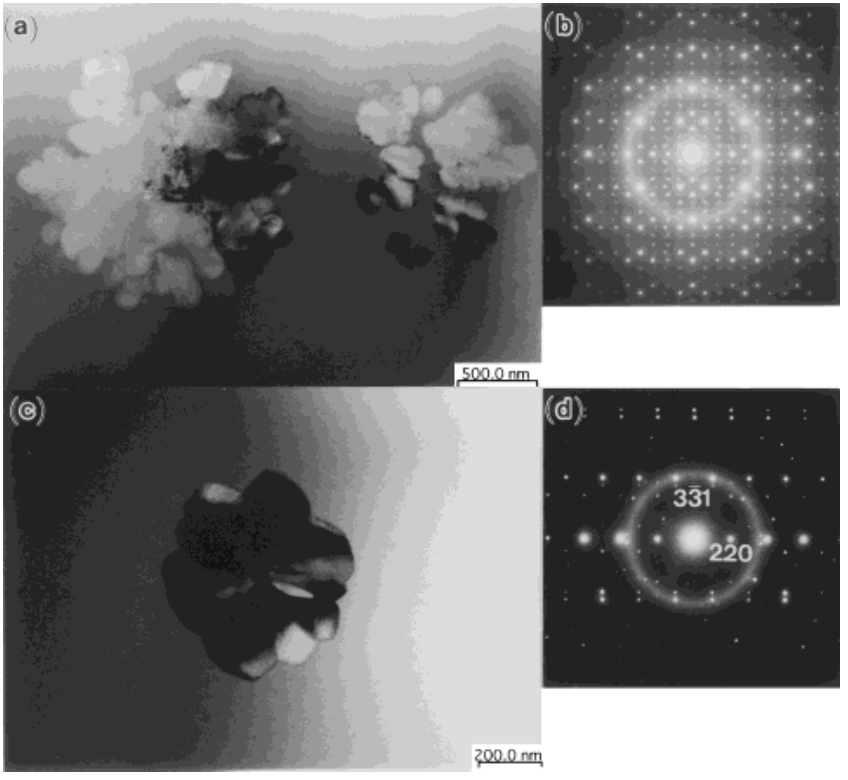

Fig. 3 Bright-field TEM images ((a), (c)) and selected-area electron diffraction patterns ((b), (d)) of the $\mathrm{Zr}_{65} \mathrm{Al}_{7.5} \mathrm{Ni}_{10} \mathrm{Cu}_{16.5} \mathrm{Pd}_{1}$ glassy alloy annealed for $30 \mathrm{~s}$ at $750 \mathrm{~K}$. The beam diameter for the selected-area electron diffraction is $1 \mu \mathrm{m}$.

along the [116] zone axis shown in (d). These two kinds of precipitates are isolated from each other and distributed homogeneously. The precipitation behavior implies the low nucleation rate considering the low distribution density and large grain size at the high annealing temperature near $T_{\mathrm{x}}$. Similar precipitation has been confirmed in the $\mathrm{Zr}_{65} \mathrm{Al}_{7.5} \mathrm{Ni}_{10} \mathrm{Cu}_{16.5}$ $(\mathrm{Ag}, \mathrm{Au} \text { and } \mathrm{Pt})_{1}$ glassy alloys annealed for short time at near $T_{\mathrm{x}}$. Thus, it is clarified that the fcc $\mathrm{Zr}_{2} \mathrm{Ni}$ and I-phases are precipitated as primary phases by substituting $\mathrm{Ag}, \mathrm{Pd}, \mathrm{Au}$ or $\mathrm{Pt}$ for 1 at\% $\mathrm{Cu}$ in the $\mathrm{Zr}_{65} \mathrm{Al}_{7.5} \mathrm{Ni}_{10} \mathrm{Cu}_{17.5}$ glassy alloy. Figure 4 shows XRD patterns of the $\mathrm{Zr}_{65} \mathrm{Al}_{7.5} \mathrm{Ni}_{10} \mathrm{Cu}_{17.5-x} \mathrm{Pd}_{x}(x=0$ to 4) glassy alloys annealed for $30 \mathrm{~s}$ at near $T_{\mathrm{x}}$. With increasing Pd content, it is found that the primary phase changes to the single I-phase. The minimum noble metal content for the precipitation of single I-phase is approximately 2 at $\%$ in the $\mathrm{Zr}_{65} \mathrm{Al}_{7.5} \mathrm{Ni}_{10} \mathrm{Cu}_{17.5}$ glassy alloy.

\subsection{Formation factor for the I-phase in Zr-based glassy alloy}

It is well known that the noble metal has a weak or positive chemical affinity with $\mathrm{Cu}$ and $\mathrm{Ni}^{1{ }^{18)}}$ The addition of noble metal in the $\mathrm{Zr}-\mathrm{Al}-\mathrm{Ni}-\mathrm{Cu}$ glassy alloy is recognized as the deviation from the three component rules for high GFA. One can, therefore expect the formation of I-phase by addition of a small amount of element except noble metal which has a weak or positive mixing enthalpy with one of the constitutional elements in the $\mathrm{Zr}-\mathrm{Al}-\mathrm{Ni}-\mathrm{Cu}$ glassy alloy. Figure 5 shows XRD patterns of the $\mathrm{Zr}_{65} \mathrm{Al}_{7.5} \mathrm{Ni}_{10} \mathrm{Cu}_{12.5}$ (V, Nb or $\mathrm{Ta})_{5}$ glassy alloys annealed for $120 \mathrm{~s}$ at temperatures of 700 and $710 \mathrm{~K}$. Since the $\mathrm{V}, \mathrm{Nb}$ and Ta have a weak or positive chemical affinities with $\mathrm{Zr}$ and $\mathrm{Cu}$ and relatively strong affinity with $\mathrm{Ni},{ }^{18)}$ we can expect the similar effect to those in noble metal addition. All of the diffraction peaks are clearly identified as an I-phase. Bright-field image (a) and nanobeam electron diffraction (NBD) patterns ((b)-(d)) of the $\mathrm{Zr}_{65} \mathrm{Al}_{7.5} \mathrm{Ni}_{10} \mathrm{Cu}_{12.5} \mathrm{Ta}_{5}$ glassy alloy annealed for $120 \mathrm{~s}$ at

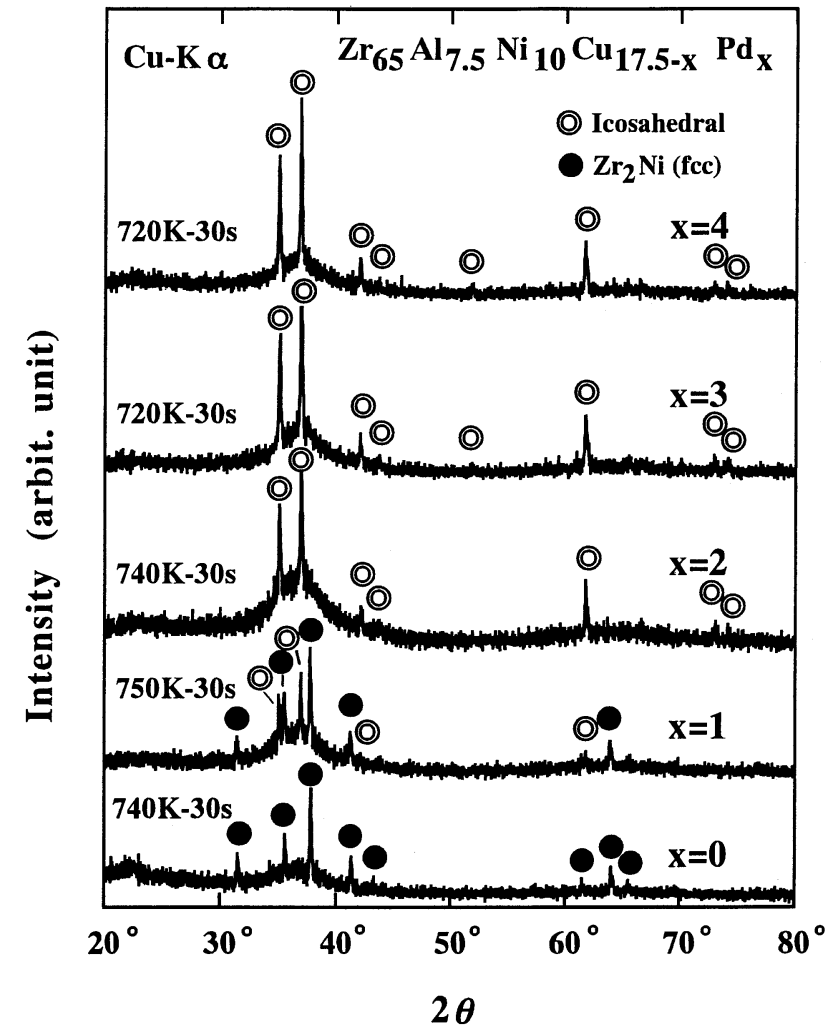

Fig. $4 \mathrm{X}$-ray diffraction patterns of the $\mathrm{Zr}_{65} \mathrm{Al}_{7.5} \mathrm{Ni}_{10} \mathrm{Cu}_{17.5-x} \mathrm{Pd}_{x}(x=0$ to 4) glassy alloys annealed for $30 \mathrm{~s}$ in a temperature range of 720 to $750 \mathrm{~K}$.

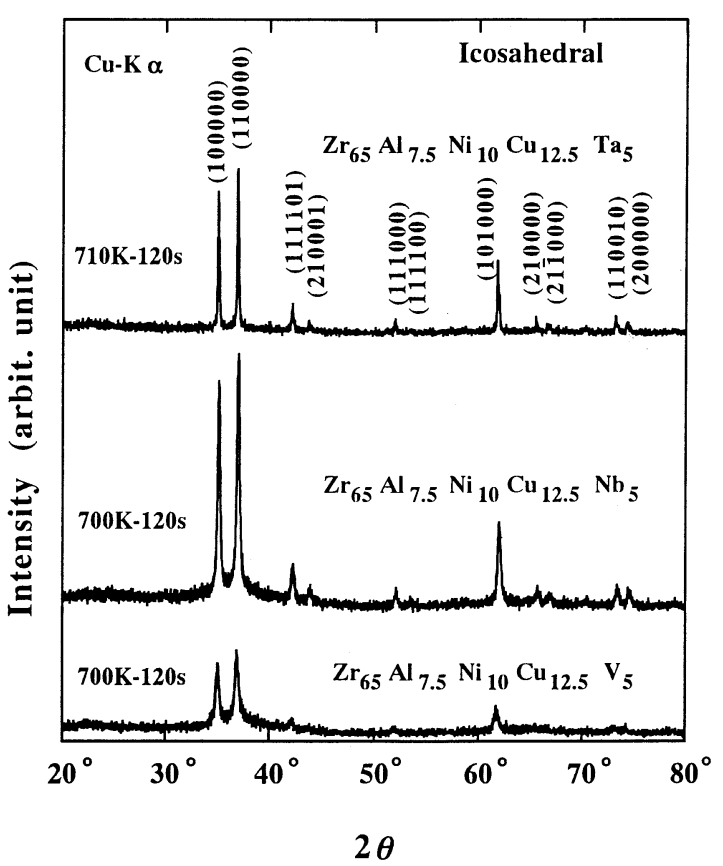

Fig. 5 X-ray diffraction patterns of the $\mathrm{Zr}_{65} \mathrm{Al}_{7.5} \mathrm{Ni}_{10} \mathrm{Cu}_{12.5}(\mathrm{~V}, \mathrm{Nb}$ and Ta) 5 glassy alloys annealed for $120 \mathrm{~s}$ at the temperatures of 700 and $710 \mathrm{~K}$.

$710 \mathrm{~K}$ are shown in Fig. 6. Very fine particles with nearly spherical morphology in the diameter of 10 to $50 \mathrm{~nm}$ are observed in (a). The NBD patterns taken from the precipitated particles with a beam diameter of approximately $2.4 \mathrm{~nm}$ denote five-, three- and two-fold symmetries, indicating the I-phase formation. These results are the same as those in 


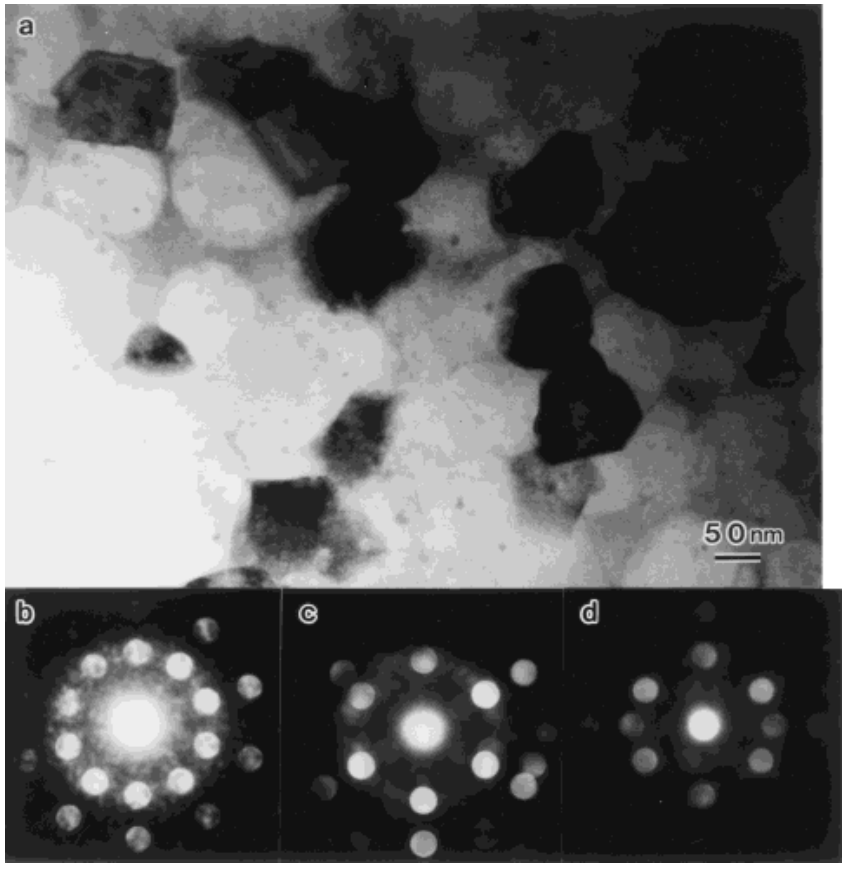

Fig. 6 Bright-field TEM image (a) and nanobeam electron diffraction patterns $((b)$ to $(d))$ of the $\mathrm{Zr}_{65} \mathrm{Al}_{7.5} \mathrm{Ni}_{10} \mathrm{Cu}_{12.5} \mathrm{Ta}_{5}$ glassy alloy annealed for $120 \mathrm{~s}$ at $710 \mathrm{~K}$. The beam diameter for nanobeam diffraction is $2.4 \mathrm{~nm}$.

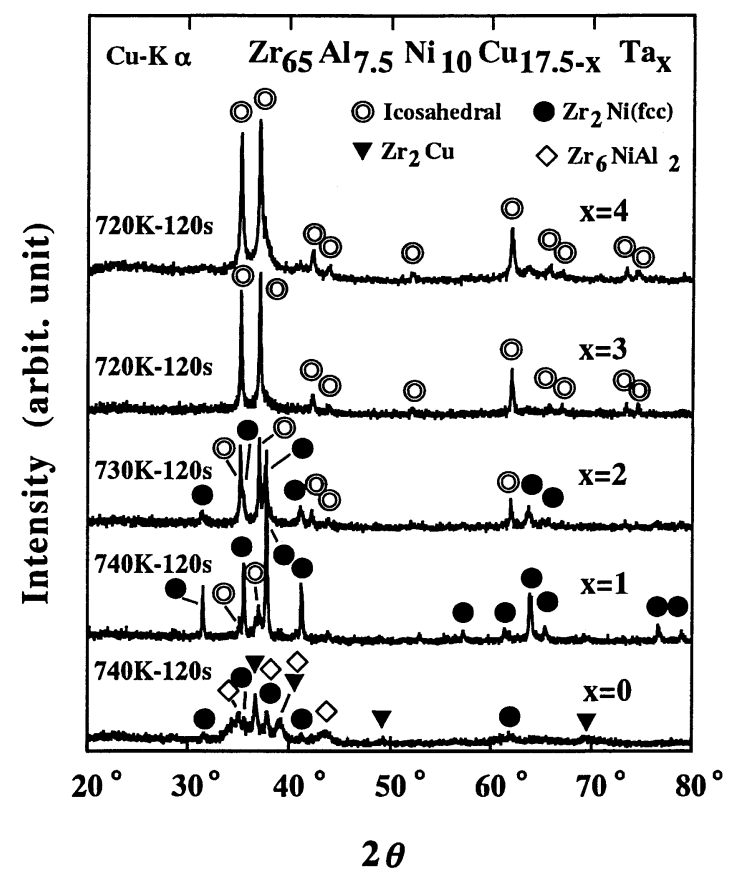

Fig. 7 X-ray diffraction patterns of the $\mathrm{Zr}_{65} \mathrm{Al}_{7.5} \mathrm{Ni}_{10} \mathrm{Cu}_{17.5-x} \mathrm{Ta}_{x}(x=1$ to 4) glassy alloys annealed for $120 \mathrm{~s}$ in a temperature range of 720 to $740 \mathrm{~K}$.

the $\mathrm{Zr}_{65} \mathrm{Al}_{7.5} \mathrm{Ni}_{10} \mathrm{Cu}_{12.5}(\mathrm{Ag}, \mathrm{Pd}, \mathrm{Au} \text { and } \mathrm{Pt})_{5}$ glassy alloys. ${ }^{9)}$ Figure 7 shows the XRD patterns of the samples annealed for $120 \mathrm{~s}$ at $T_{\mathrm{x}}$ in the $\mathrm{Zr}_{65} \mathrm{Al}_{7.5} \mathrm{Ni}_{10} \mathrm{Cu}_{17.5-x} \mathrm{Ta}_{x}(x=1$ to 4$)$ alloys. In the 1 at\% Ta-containing alloy, the primary phase is an fcc $\mathrm{Zr}_{2} \mathrm{Ni}$ as a main phase accompanying the weak peak corresponding to the I-phase. It is realized as the same results as those with the noble metal addition in the $\mathrm{Zr}_{65} \mathrm{Al}_{7.5} \mathrm{Ni}_{10} \mathrm{Cu}_{17.5}$ glassy alloy. In the 2 at $\%$ Ta alloy, the I-phase is observed as a main precipitation phase together with a small amount of the fcc $\mathrm{Zr}_{2} \mathrm{Ni}$ phase. Subsequently, it is found that only the I-phase is formed as a primary phase in the alloys with Ta contents above 3 at $\%$. Thus, it is found that the main precipitates change drastically from the fcc $\mathrm{Zr}_{2} \mathrm{Ni}$ phase to the I-phase with increasing Ta content. The additional elements for the I-phase formation in the $\mathrm{Zr}-\mathrm{Al}-\mathrm{Ni}-\mathrm{Cu}$ glassy alloy are summarized in Table $1.8,9,11,12,19-24)$ The table contains the atomic radius and mixing enthalpies with $\mathrm{Zr}, \mathrm{Al}, \mathrm{Ni}$ and $\mathrm{Cu}$ of the additional elements. It is found that all additional elements have weak or positive mixing enthalpies with one constitutional element at least in $\mathrm{Zr}-\mathrm{Al}-\mathrm{Ni}-\mathrm{Cu}$ glassy alloy. These results indicate that the slight deviation from the three component rules is very effective for the I-phase formation.

There is a possibility that an I-phase is precipitated by the slight change of the alloy composition with high GFA instead of addition of the element deviated from the three component rules. Figure 8 shows DSC curves of the melt-spun $\mathrm{Zr}_{65+y} \mathrm{Al}_{7.5} \mathrm{Ni}_{10} \mathrm{Cu}_{17.5-y}(y=0$ to 9$)$ glassy alloys. A single sharp exothermic peak is clearly seen after the glass transition at $y=0$ to 3 . Although the peak temperature of the first sharp exothermic reaction decreases with increasing $\mathrm{Zr}$ content, the supercooled liquid region defined by the temperature interval between the glass transition temperature $T_{\mathrm{g}}$ and crystallization temperature, $T_{\mathrm{x}}$, is almost constant at approximately $110 \mathrm{~K}$. The first sharp exothermic reaction is divided into two peaks above $y=5$ accompanying a significant decrease in the supercooled liquid region. In order to examine the primary phase crystallized from the glassy state, the glassy alloy ribbons were annealed at $T_{\mathrm{x}}$. Figure 9 shows XRD patterns of the samples annealed for $120 \mathrm{~s}$ at $T_{\mathrm{x}}$. Mixture phases of fcc $\mathrm{Zr}_{2} \mathrm{Ni}, \mathrm{Zr}_{2} \mathrm{Cu}$ and $\mathrm{Zr}_{6} \mathrm{NiAl}_{2}$ are formed at $y=0$. It is reported that the nearly single fcc $\mathrm{Zr}_{2} \mathrm{Ni}$ phase is precipitated as the primary phase in the $\mathrm{Zr}_{65} \mathrm{Al}_{7.5} \mathrm{Ni}_{10} \mathrm{Cu}_{17.5}$ glassy alloy annealed for $30 \mathrm{~s}$ at $740 \mathrm{~K}$ as shown in Fig. 2. It is, therefore recognized that the $\mathrm{Zr}_{2} \mathrm{Cu}$ and $\mathrm{Zr}_{6} \mathrm{NiAl}_{2}$ phases appear immediately after the precipitation of the fcc $\mathrm{Zr}_{2} \mathrm{Ni}$ phase. A weak diffraction peak corresponding to an I-phase is observed in addition to the mixture phases of fcc $\mathrm{Zr}_{2} \mathrm{Ni}, \mathrm{Zr}_{2} \mathrm{Cu}$ and $\mathrm{Zr}_{6} \mathrm{NiAl}_{2}$ at $y=1$. Subsequently, the primary phase changes to the single I-phase in the range of $y=3$ to 5 . The intensity of diffraction peaks corresponding to the I-phase decreases significantly and the bcc $\mathrm{Zr}$ phase is precipitated above $y=7$. Finally, no I-phase is observed at $y=9$. Bright-field TEM image and $\mathrm{SADP}$ of the $\mathrm{Zr}_{70} \mathrm{Al}_{7.5} \mathrm{Ni}_{10} \mathrm{Cu}_{12.5}(y=5)$ alloy annealed for $60 \mathrm{~s}$ at $710 \mathrm{~K}$ are shown in Figs. 10(a) and (b), respectively. Dendritic particle with a diameter of approximately $2000 \mathrm{~nm}$ is observed in the bright-field image. The number of the precipitated particle is very few, which implies low nucleation rate and/or large grain growth rate. The SADP clearly reveals a fivefold symmetry, which is characterized as the icosahedral structure.

It is concluded that the slight deviation from the three component rules for high GFA by either addition of the element with a weak or positive chemical affinity with one of the constitutional elements or a change from the alloy composition with high GFA, is an important factor for the formation of the I-phase in the Zr-based glassy alloy. 
Table 1 Additional elements for the I-phase formation in the $\mathrm{Zr}-\mathrm{Al}-\mathrm{Ni}-\mathrm{Cu}$ glassy alloy. The atomic sizes and mixing enthalpies with $\mathrm{Zr}, \mathrm{Al}, \mathrm{Ni}$ and $\mathrm{Cu}$ are also denoted in the table.

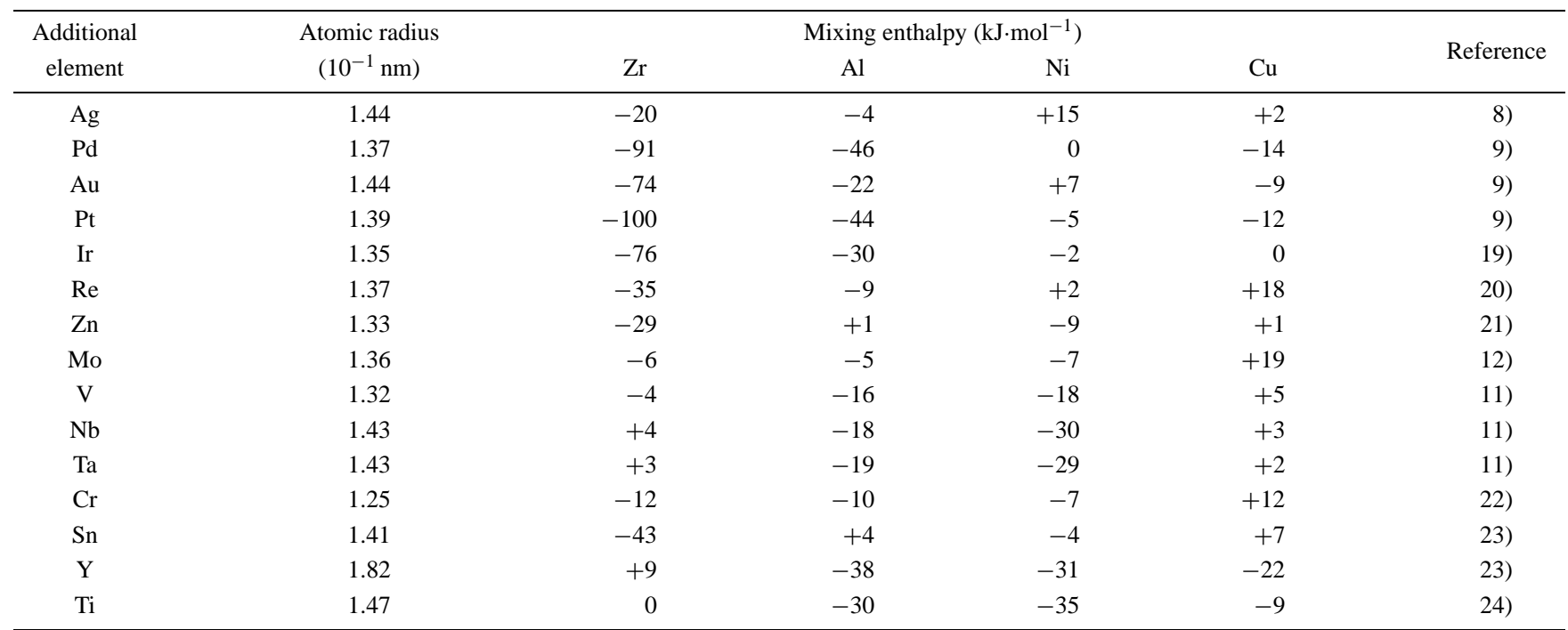

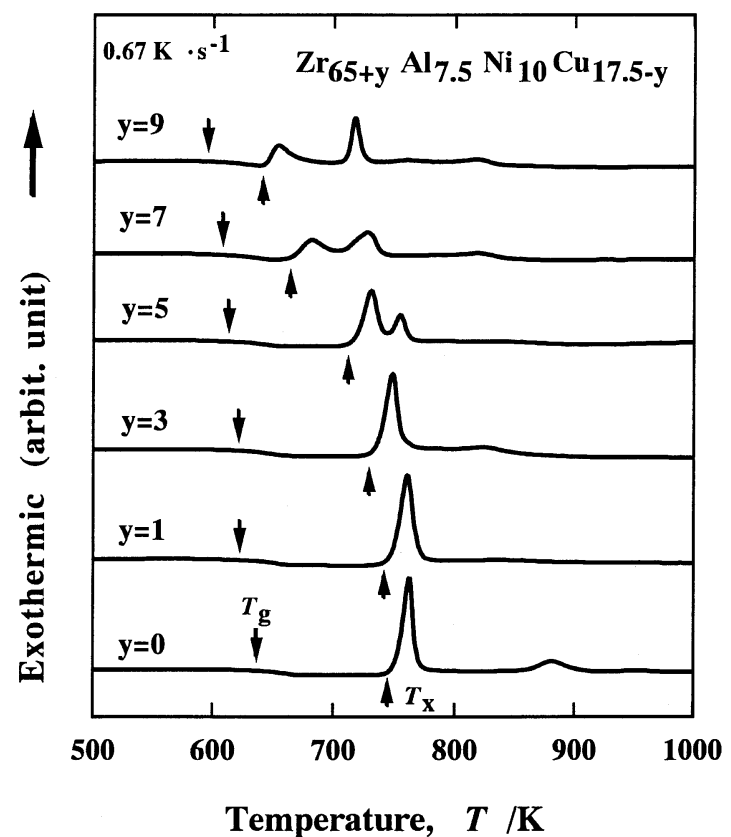

Fig. 8 DSC curves of the $\mathrm{Zr}_{65+y} \mathrm{Al}_{7.5} \mathrm{Ni}_{10} \mathrm{Cu}_{17.5-y}(y=0$ to 9) glassy alloys.

\section{Discussion}

\subsection{Effect of noble metal on transformation from glassy to I-phase}

The effect of noble metal on the transformation behavior from the glassy to I-phase is examined. Figure 11 shows the change in DSC curves of the melt-spun $\mathrm{Zr}_{65} \mathrm{Al}_{7.5} \mathrm{Ni}_{10} \mathrm{Cu}_{17.5-x} \mathrm{Pd}_{x}(x=0$ to 4$)$ glassy alloys. As shown in Fig. 4, the primary phase changes drastically from the fcc $\mathrm{Zr}_{2} \mathrm{Ni}$ to I-phase with increasing Pd content. Corresponding to the change in the primary phase, the crystallization reaction changes from a sharp single exothermic peak into more than two peaks and the temperature gap between the two exothermic peaks increases with increasing Pd con-

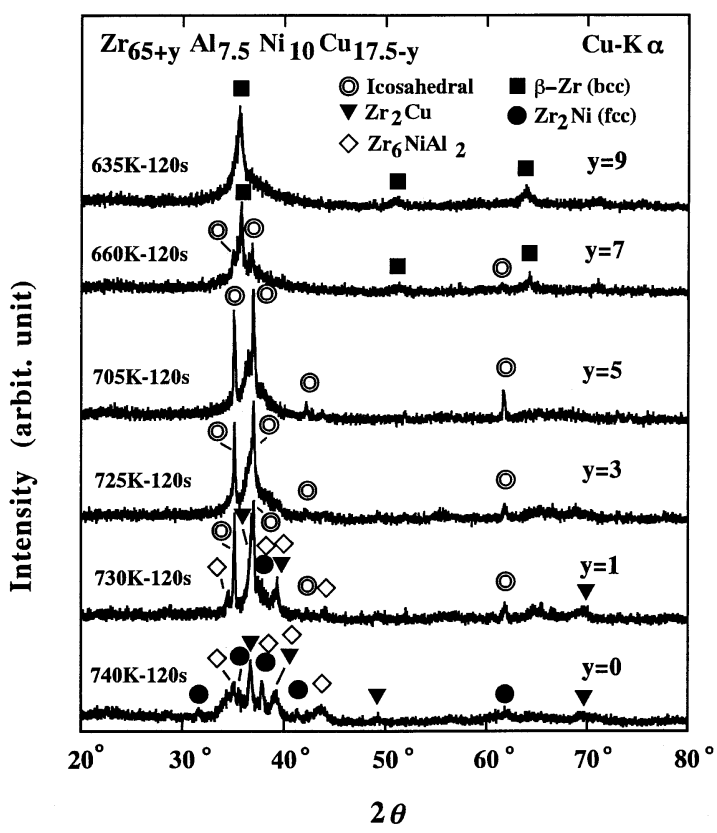

Fig. 9 X-ray diffraction patterns of the $\mathrm{Zr}_{65+y} \mathrm{Al}_{7.5} \mathrm{Ni}_{10} \mathrm{Cu}_{17.5-y}(y=0$ to 9) glassy alloys annealed for $120 \mathrm{~s}$ in a temperature range of 635 to $740 \mathrm{~K}$.

tent. The first exothermic reaction is corresponding to the precipitation of an I-phase in the Pd content above 2 at $\%$. Although the exothermic reaction has a single peak in the 1 at\%Pd alloy, the peak is broader than that of the Pd-free alloy and the fcc- $\mathrm{Zr}_{2} \mathrm{Ni}$ and I-phases precipitate simultaneously at the initial crystallization stage. Considering that the onset temperature of the first exothermic reaction decreases with increasing Pd content, it is suggested that the nucleation is enhanced by Pd addition. The authors have reported that the grain size of the I-phase decreases significantly as $\mathrm{Pd}$ content increases in the glassy alloy. ${ }^{25)}$ It is recognized as a significant increase in nucleation rate of the I-phase with an increase of Pd content. We have also reported the effect of addition of noble metals such as $\mathrm{Ag}$ and $\mathrm{Pd}$ on the nucleation and grain growth of the I-phase in the Zr-based glassy 


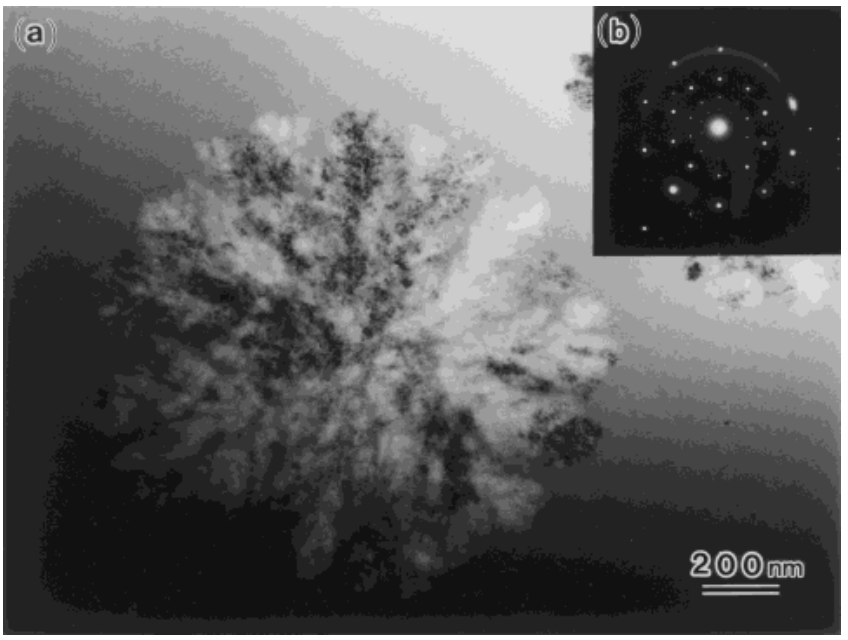

Fig. 10 Bright-field TEM image (a) and selected-area electron diffraction pattern (b) of the $\mathrm{Zr}_{70} \mathrm{Al}_{7.5} \mathrm{Ni}_{10} \mathrm{Cu}_{12.5}$ glassy alloy annealed for $60 \mathrm{~s}$ at $710 \mathrm{~K}$. The beam diameter for the selected-area electron diffraction is $1 \mu \mathrm{m}$.

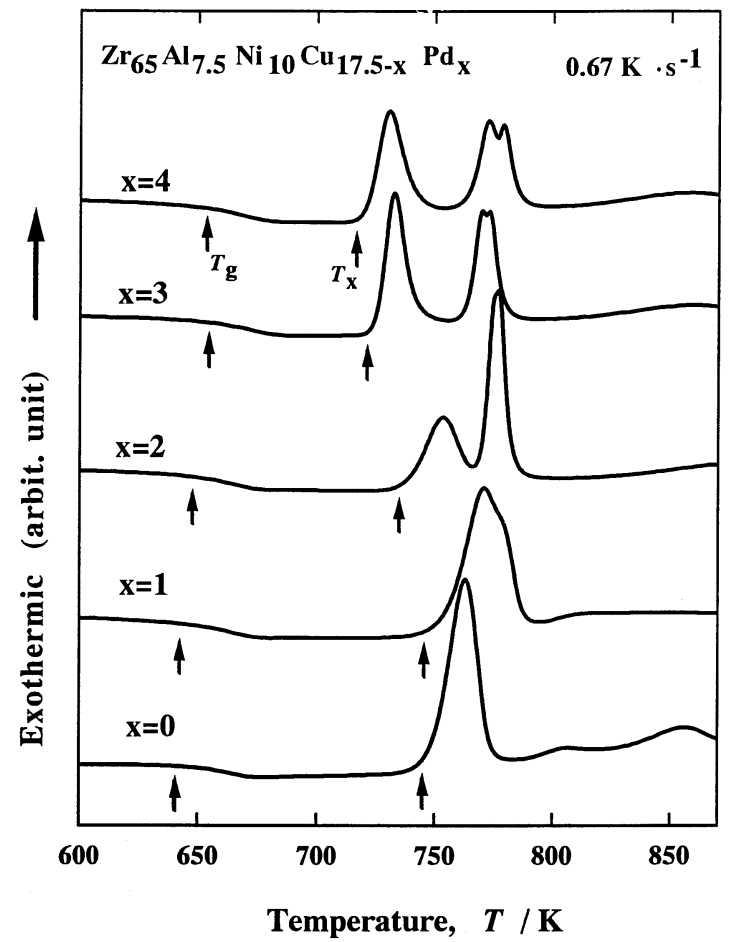

Fig. 11 DSC curves of the $\mathrm{Zr}_{65} \mathrm{Al}_{7.5} \mathrm{Ni}_{10} \mathrm{Cu}_{17.5-x} \mathrm{Pd}_{x}$ ( $x=0$ to 4 ) glassy alloys.

alloys. $^{26,27)}$ The nucleation rate increases significantly from $10^{16}$ to $10^{20} \mathrm{~m}^{-3} \mathrm{~s}^{-1}$ and the grain growth rate decreases from approximately $10^{-8}$ to $10^{-9} \mathrm{~ms}^{-1}$ by addition of 10 at $\% \mathrm{Ag}$ or $\mathrm{Pd}$ in the $\mathrm{Zr}_{65} \mathrm{Al}_{7.5} \mathrm{Ni}_{10} \mathrm{Cu}_{7.5} \mathrm{M}_{10}(\mathrm{M}=\mathrm{Ag}$ or $\mathrm{Pd})$ glassy alloys. Based on the J-M-A analysis, ${ }^{26,28)}$ the calculated homogeneous nucleation rates, $I_{\mathrm{v}}$ of the primary phase at $T_{\mathrm{x}}$ in the $\mathrm{Zr}_{65} \mathrm{Al}_{7.5} \mathrm{Ni}_{10} \mathrm{Cu}_{17.5-x} \mathrm{Pd}_{x}(x=0,5,10$ and 17.5) glassy alloys are plotted in Fig. 12. It increases with increasing Pd content, indicating a decline of resistance for crystallization by the addition of $\mathrm{Pd}$. The $I_{\mathrm{v}}$ is $(2.6 \pm 0.3) \times 10^{16} \mathrm{~m}^{-3} \mathrm{~s}^{-1}$ for the precipitation of the fcc $\mathrm{Zr}_{2} \mathrm{Ni}$ phase at $x=0$. Since the grain size of the I-phase is similar to that of the fcc $\mathrm{Zr}_{2} \mathrm{Ni}$ phase in the $\mathrm{Zr}_{65} \mathrm{Al}_{7.5} \mathrm{Ni}_{10} \mathrm{Cu}_{16.5} \mathrm{Pd}_{1}$ glassy alloy, we can estimate the

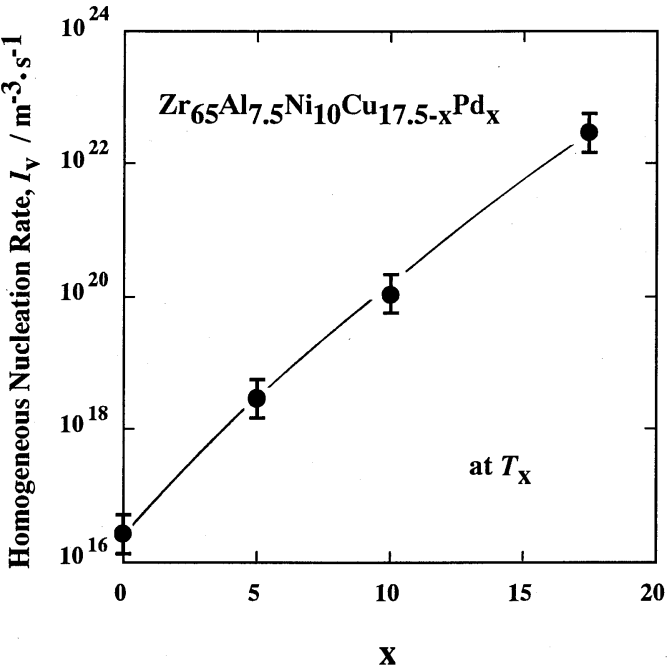

Fig. 12 Calculated homogeneous nucleation rate, $I_{\mathrm{V}}$ of the primary phase at $T_{\mathrm{X}}$ in the $\mathrm{Zr}_{65} \mathrm{Al}_{7.5} \mathrm{Ni}_{10} \mathrm{Cu}_{17.5-x} \mathrm{Pd}_{x}(x=0,5,10$ and 17.5) glassy alloys.

nucleation rate of the I-phase as an order of $10^{16} \mathrm{~m}^{-3} \mathrm{~s}^{-1}$. The $I_{\mathrm{v}}$ increases significantly to $(2.9 \pm 0.3) \times 10^{18} \mathrm{~m}^{-3} \mathrm{~s}^{-1}$ for the precipitation of the I-phase by the addition of only 5 at\% Pd and increases almost linearly with increasing Pd content. The $I_{\mathrm{v}}$ increases to $(1.1 \pm 0.3) \times 10^{20} \mathrm{~m}^{-3} \mathrm{~s}^{-1}$ for $x=10$ and $(2.9 \pm 0.3) \times 10^{22} \mathrm{~m}^{-3} \mathrm{~s}^{-1}$ for $x=17.5$. The nucleation rate of the I-phase at $\mathrm{Pd}=5$ at $\%$ is nearly equal to that of the I-phase in the $\mathrm{Zr}_{69.5} \mathrm{Al}_{7.5} \mathrm{Ni}_{11} \mathrm{Cu}_{12}$ glassy alloy, which contains a large amount of oxygen impurity. ${ }^{29)}$ It is therefore, concluded that the significant increase in the homogeneous nucleation rate by addition of a small amount of Pd leads to precipitation of an I-phase, which implies an introduction of icosahedral shortor medium-range ordered structures in the glassy state of the $\mathrm{Zr}-\mathrm{Al}-\mathrm{Ni}-\mathrm{Cu}$ alloy. It is also suggested that the significant increase in the homogeneous nucleation rate occurs by addition of other elements as well as noble metal, which have a weak or positive affinity with one of the constituent elements in the $\mathrm{Zr}-\mathrm{Al}-\mathrm{Ni}-\mathrm{Cu}$ glassy alloy.

Finally, it is important to concern the possibility of the drastic change of local structure in the glassy state by addition of noble metal in $\mathrm{Zr}-\mathrm{Al}-\mathrm{Ni}-\mathrm{Cu}$ alloy. In the $\mathrm{Zr}_{65} \mathrm{Al}_{7.5} \mathrm{Ni}_{10} \mathrm{Cu}_{16.5} \mathrm{Pd}_{1}$ glassy alloy, the fcc $\mathrm{Zr}_{2} \mathrm{Ni}$ and Iphases are isolated each other and homogeneously distributed in the glassy matrix. The average compositions of five data points analyzed by nanobeam EDX for the fcc $\mathrm{Zr}_{2} \mathrm{Ni}$, Iand residual glassy phases are $\mathrm{Zr}_{69.3} \mathrm{Al}_{6.9} \mathrm{Ni}_{11.6} \mathrm{Cu}_{11.2} \mathrm{Pd}_{1.0}$, $\mathrm{Zr}_{72.7} \mathrm{Al}_{7.3} \mathrm{Ni}_{6.9} \mathrm{Cu}_{12.0} \mathrm{Pd}_{1.1}$ and $\mathrm{Zr}_{63.9} \mathrm{Al}_{6.8} \mathrm{Ni}_{10.1} \mathrm{Cu}_{18.5} \mathrm{Pd}_{0.7}$, respectively. Considering that the fcc $\mathrm{Zr}_{2} \mathrm{Ni}$ and I-phases have a similar Pd content and the precipitates consisting of the two phases are isolated each other at the initial crystallization stage, it implies that the local structure does not change by addition of 1 at $\% \mathrm{Pd}$. Therefore, it is realized that the I-phase can be formed without a significant local structural change by addition of $\mathrm{Pd}$ into the $\mathrm{Zr}-\mathrm{Al}-\mathrm{Ni}-\mathrm{Cu}$ glassy alloy.

\subsection{Structural correlation between fcc- $\mathrm{Zr}_{2} \mathrm{Ni}$ and I- phases}

By the investigation on the change in the nucleation behavior of the I-phase with Pd content, we obtained the conclusion 
that Pd plays an important role in an increase in the nucleation rate of the primary phase. Although the mechanism for the I-phase formation seems to be not simple in spite of the present results, we can point out that the I-phase formation is attributed to an increase in the nucleation rate. Moreover, the novel local structure in the glassy state of the $\mathrm{Zr}-\mathrm{Al}-\mathrm{Ni}-$ $\mathrm{Cu}$ alloy is recognized as one of the important factors for the precipitation of the I-phase. The structural analyses in the $\mathrm{Zr}_{65} \mathrm{Al}_{7.5} \mathrm{Ni}_{10} \mathrm{Cu}_{17.5}$ glassy alloy indicate that the fcc $\mathrm{Zr}_{2} \mathrm{Ni}$ phase precipitates as a primary phase. The primary phase changes from the fcc $\mathrm{Zr}_{2} \mathrm{Ni}$ phase to the I-phase by adding a small amount of $\mathrm{Pd}$. As discussed in 4.1., the local structure does not change drastically by a small amount of Pd addition. This is also supported from the microstructure analysis of the fcc $\mathrm{Zr}_{2} \mathrm{Ni}$ and I-phases in the $\mathrm{Zr}_{65} \mathrm{Al}_{7.5} \mathrm{Ni}_{10} \mathrm{Cu}_{16.5} \mathrm{Pd}_{1}$ glassy alloy, where both the phases precipitate in the completely isolated state each other. This result suggests that the fcc $\mathrm{Zr}_{2} \mathrm{Ni}$ and I-phases are originated from the same local structure in the glassy state. Figure 13(a) shows a schematic drawing of the unit cell of the fcc $\mathrm{Zr}_{2} \mathrm{Ni}$ structure. ${ }^{30)}$ This crystalline structure, which is sometimes called a big-cube phase, has a large lattice constant of $1.227 \mathrm{~nm}$ and contains $64 \mathrm{Zr}$ and $32 \mathrm{Ni}$ atoms. The structure consisted of icosahedral clusters of $\mathrm{Zr}$ and $\mathrm{Ni}$ atoms. As an example, two icosahedral clusters around $\mathrm{Zr}$ and $\mathrm{Ni}$ are picked up from the unit cell in Fig. 13(b). Considering that the fcc $\mathrm{Zr}_{2} \mathrm{Ni}$ and I-phases contain an icosahedron in the unit cell, ${ }^{31,32)}$ we can point out that an icosahedral short- or medium-range order exists in the $\mathrm{Zr}-\mathrm{Al}-\mathrm{Ni}-\mathrm{Cu}$ glassy alloy, which can grow as an icosahedral quasicrystalline phase under high nucleation rate by a small amount of $\mathrm{Pd}$ addition. It is presumed that the $\mathrm{Pd}$ is effective for the enhancement for the distortion of the icosahedron in the unit cell of fcc $\mathrm{Zr}_{2} \mathrm{Ni}$ structure, which is also one of the factors for the precipitation of I-phase by adding Pd in the $\mathrm{Zr}-\mathrm{Al}-\mathrm{Ni}-\mathrm{Cu}$ glassy alloy.

Based on the previously reported experimental data for $\mathrm{Zr}$ based glassy alloys, ${ }^{33)}$ it has been clarified that the glassy alloys can have (a) higher degrees of dense randomly packed atomic configurations, (b) new local atomic configurations, which are different from those of the corresponding final crystalline phases, and (c) homogeneous atomic configurations of the multicomponents on a long-range scale. Assuming the existence of an icosahedral short- or medium-range or-

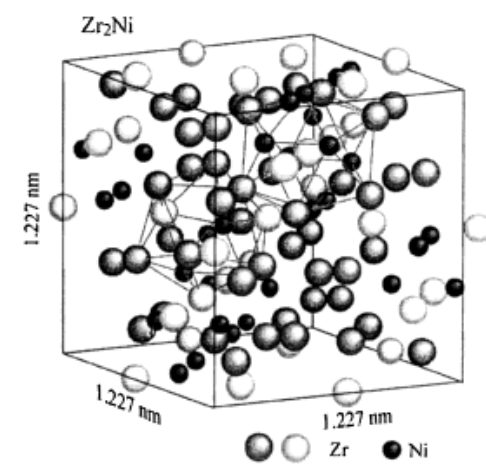

(a)

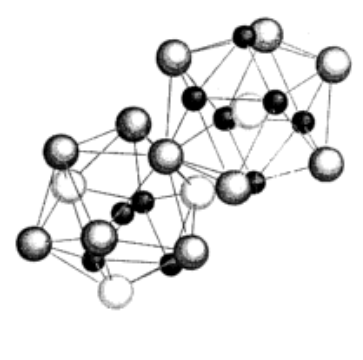

(b)
Fig. 13 Schematic drawings of the unit cell of fcc $\mathrm{Zr}_{2} \mathrm{Ni}$ structure (a) and examples of icosahedral clusters around $\mathrm{Zr}$ and $\mathrm{Ni}$ atoms in the unit cell (b). der, it satisfies the above-described criteria. It is therefore, pointed out that the icosahedral short- or medium-range order may stabilize the glassy state in the $\mathrm{Zr}-\mathrm{Al}-\mathrm{Ni}-\mathrm{Cu}$ glassy alloy where the icosahedral order restraints the long-range rearrangements of constitutional atoms to form the ordinary crystalline phases. Finally, it is interpreted that the mechanism for the I-phase precipitation by addition of other noble metals and elements is the same as that by addition of Pd in the $\mathrm{Zr}$-based glassy alloy.

\subsection{Observation of the local structure in the glassy state}

In order to examine an icosahedral order in the glassy state, we performed HREM observation for the as-quenched glassy alloy. Figure 14 shows HREM image (a) and SADP (b) of the $\mathrm{Zr}_{70} \mathrm{Al}_{7.5} \mathrm{Ni}_{10} \mathrm{Cu}_{12.5}$ glassy alloy. The SADP consists of only a halo ring, indicating a glassy structure. It is found that the image has some features of local regions in the asquenched sample, which are circled in Fig. 14(a). The size of the encircled local regions is below $2 \mathrm{~nm}$. We could not obtain any NBD patterns except a halo ring from the encircled local region with the extremely small size. The encircled local regions have a similar feature as those in the dense random packed (DRP) structure in the glassy alloy. However, the size of the region is considerably larger than that in the DRP structure, indicating a possibility of the local ordered region. Xing et al. have reported the similar HREM image in the asquenched $\mathrm{Zr}_{54.5} \mathrm{Ti}_{7.5} \mathrm{Cu}_{20} \mathrm{Ni}_{8} \mathrm{Al}_{10}$ glassy alloy, ${ }^{15)}$ in which the I-phase is also formed in the annealed state. They suggest that the local region is recognized as the ordered structure, which is indicative of icosahedral short- or medium-range order. Moreover, a similar structure has been reported in the simulation result where the icosahedral short-range order is assumed to exist in the glassy state. ${ }^{34)}$ Very recently, similar local ordered regions are confirmed in the quasicrystalforming $\mathrm{Zr}_{70} \mathrm{Pd}_{30}$ glassy alloy. ${ }^{35,36)}$ Since the NBD pattern taken from them reveals the fivefold symmetry, it is clarified that the local ordered region has the icosahedral structure. ${ }^{37)}$ It may be therefore, thought that the local region observed in the as-quenched $\mathrm{Zr}_{70} \mathrm{Al}_{7.5} \mathrm{Ni}_{10} \mathrm{Cu}_{12.5}$ glassy alloy is realized as an icosahedral short- or medium-range order.

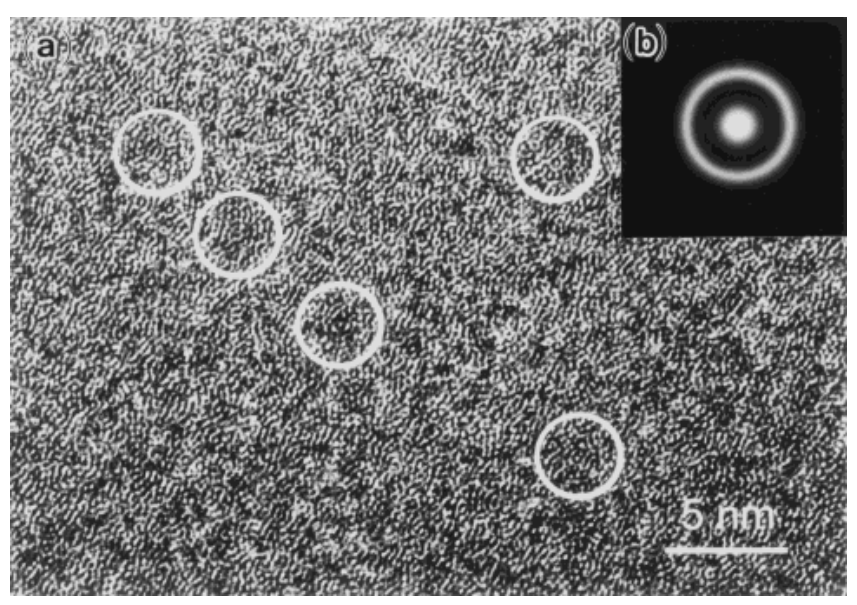

Fig. 14 High-resolution transmission electron microscopy image (a) and selected-area electron diffraction pattern (b) of the melt-spun $\mathrm{Zr}_{70} \mathrm{Al}_{7.5} \mathrm{Ni}_{10} \mathrm{Cu}_{12.5}$ glassy alloy. The beam diameter for the selected-area electron diffraction is $1 \mu \mathrm{m}$. 


\subsection{Investigation of stability of supercooled liquid state in Zr-based alloy}

It is well known that high GFA is attributed to a high stability of the supercooled liquid state. ${ }^{38)}$ We obtain the conclusions that the icosahedral short- or medium-range order exists in the glassy state and it retards the rearrangement of the constitutional elements for crystallization, leading to the appearance of high GFA in the Zr-based alloys. It is, therefore suggested that the icosahedral short- or medium-range order stabilizes the supercooled liquid state. It is very important to clarify the origin of the atomic pair for the appearance of the stable supercooled liquid state in the $\mathrm{Zr}$-based alloys. In the Zr-based alloy systems, the $\mathrm{Zr}-\mathrm{Cu}$ binary alloy exhibits a distinct glass transition in the wide compositional range, ${ }^{39)} \mathrm{im}$ plying the existence of the novel local structure with an icosahedral atomic configuration. Several studies on the I-phase formation by a comparatively large amount of addition of 7 to 20 at $\% \mathrm{Pd}$, Pt, Ir or $\mathrm{Rh}$ in the $\mathrm{Zr}-\mathrm{Cu}$ glassy alloy have been reported. ${ }^{40-43)}$ These results are consistent with the suggestion of the existence of icosahedral short- or medium-range order in the $\mathrm{Zr}-\mathrm{Cu}$ glassy alloy. For further confirmation of the existence of the icosahedral short- or medium-range order, change in the phase transformation behavior by substituting $\mathrm{Pd}$, $\mathrm{Au}$ or $\mathrm{Pt}$ for 1 at $\% \mathrm{Cu}$ in the $\mathrm{Zr}_{70} \mathrm{Cu}_{30}$ glassy alloy is examined. Figures 15 and 16 show DSC curves of the $\mathrm{Zr}_{70} \mathrm{Cu}_{30}$ and $\mathrm{Zr}_{70} \mathrm{Cu}_{29}$ ( $\mathrm{Pd}, \mathrm{Au}$ or $\left.\mathrm{Pt}\right)_{1}$ melt-spun ribbons and XRD patterns of the samples annealed for $120 \mathrm{~s}$ at the temperatures between 620 and $655 \mathrm{~K}$, respectively. The single sharp exothermic reaction is observed after the significant glass transition in the $\mathrm{Zr}_{70} \mathrm{Cu}_{30}$ alloy in Fig. 15. The onset temperatures of glass transition, $T_{\mathrm{g}}$ and the exothermic peak, $T_{\mathrm{x}}$ are $627 \mathrm{~K}$ and $676 \mathrm{~K}$, respectively. It is observed that the exothermic peak is clearly separated by addition of 1 at $\% \mathrm{Pd}$, $\mathrm{Au}$ or Pt with remaining the glass transition. The separation of the exothermic peak in the $\mathrm{Au}$ - and Pt-containing alloys is more distinct than that in the Pd-containing alloy. In the XRD patterns, very sharp diffraction peaks are observed and all of them are identified as the $\mathrm{Zr}_{2} \mathrm{Cu}$ phase in the $\mathrm{Zr}_{70} \mathrm{Cu}_{30}$ glassy alloy. Meanwhile, it is found that the diffraction peaks in addition to the halo peak in the $\mathrm{Zr}_{70} \mathrm{Cu}_{29}(\mathrm{Pd}, \mathrm{Au} \text { or } \mathrm{Pt})_{1}$ alloys are completely different from those in the $\mathrm{Zr}_{70} \mathrm{Cu}_{30}$ alloy. All diffraction peaks in the $\mathrm{Zr}_{70} \mathrm{Cu}_{29}$ (Pd, $\mathrm{Au}$ or $\left.\mathrm{Pt}\right)_{1}$ glassy alloys can be identified as an icosahedral quasicrystalline phase.

For the confirmation of the icosahedral phase formation and the examination of morphology of the I-phase, we performed transmission electron microscopic observation for the annealed glassy alloys. Figure 17 shows bright-field image (a) and nanobeam electron diffraction (NBD) patterns with a beam diameter of $2.4 \mathrm{~nm}((\mathrm{~b})-(\mathrm{d}))$ of the $\mathrm{Zr}_{70} \mathrm{Cu}_{29} \mathrm{Pd}_{1}$ glassy alloy annealed for $120 \mathrm{~s}$ at $620 \mathrm{~K}$. A bright-field image of the $\mathrm{Zr}_{70} \mathrm{Cu}_{30}$ glassy alloy annealed for $120 \mathrm{~s}$ at $655 \mathrm{~K}$ is also shown for comparison in Fig. 17(e). The coarse $\mathrm{Zr}_{2} \mathrm{Cu}$ particles with a nearly cuboid morphology are observed over the whole area in the $\mathrm{Zr}_{70} \mathrm{Cu}_{30}$ alloy. The particle size is in range of 200 to $400 \mathrm{~nm}$ in diameter. In contrast, very fine particles in the diameter range less than $50 \mathrm{~nm}$ are precipitated in the $\mathrm{Zr}_{70} \mathrm{Cu}_{29} \mathrm{Pd}_{1}$ alloy, indicating the high nucleation rate. The particles have a nearly spherical morphology. The NBD patterns taken from the particles shown in (b) to (d) clearly indicate five-, three- and two-fold symmetries, which are identi-

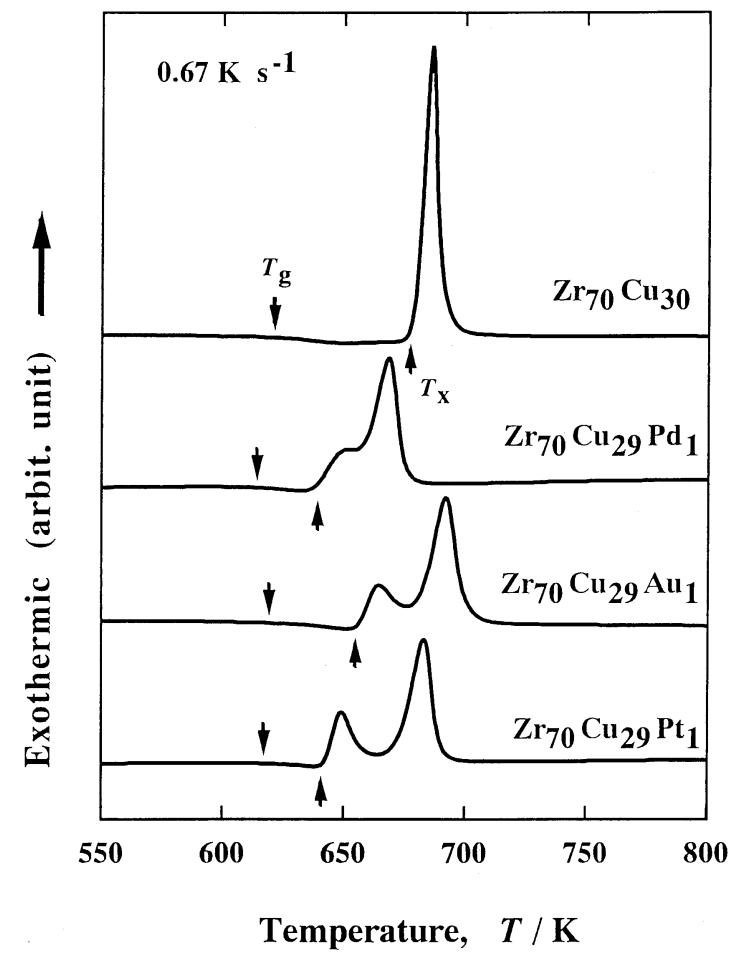

Fig. 15 DSC curves of the $\mathrm{Zr}_{70} \mathrm{Cu}_{30}$ and $\mathrm{Zr}_{70} \mathrm{Cu}_{29}(\mathrm{Pd}, \mathrm{Au} \text { and } \mathrm{Pt})_{1}$ glassy alloys.

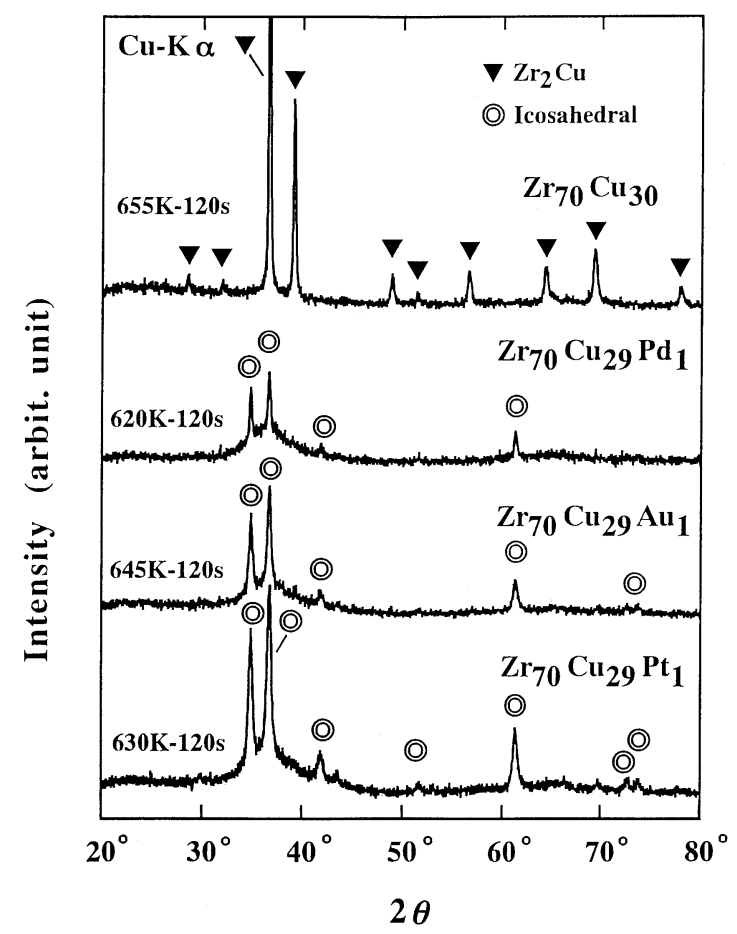

Fig. 16 X-ray diffraction patterns of the $\mathrm{Zr}_{70} \mathrm{Cu}_{30}$ and $\mathrm{Zr}_{70} \mathrm{Cu}_{29}(\mathrm{Pd}, \mathrm{Au}$ and $\mathrm{Pt})_{1}$ glassy alloys annealed for $120 \mathrm{~s}$ in the temperature range of 620 to $655 \mathrm{~K}$.

fied as the icosahedral quasicrystalline phase. Similar images and NBD patterns are obtained in the annealed $\mathrm{Zr}_{70} \mathrm{Cu}_{29}$ (Au and $\mathrm{Pt})_{1}$ alloys for $120 \mathrm{~s}$ at 645 and $630 \mathrm{~K}$, respectively. Thus, we can conclude that the nano I-phase is formed as a primary metastable phase by substituting Pd, Au or Pt for only 1 at $\% \mathrm{Cu}$ in the $\mathrm{Zr}_{70} \mathrm{Cu}_{30}$ glassy alloy. These results are in a good agreement with those in the $\mathrm{Zr}_{65} \mathrm{Al}_{7.5} \mathrm{Ni}_{10} \mathrm{Cu}_{16.5}(\mathrm{Ag}$, 


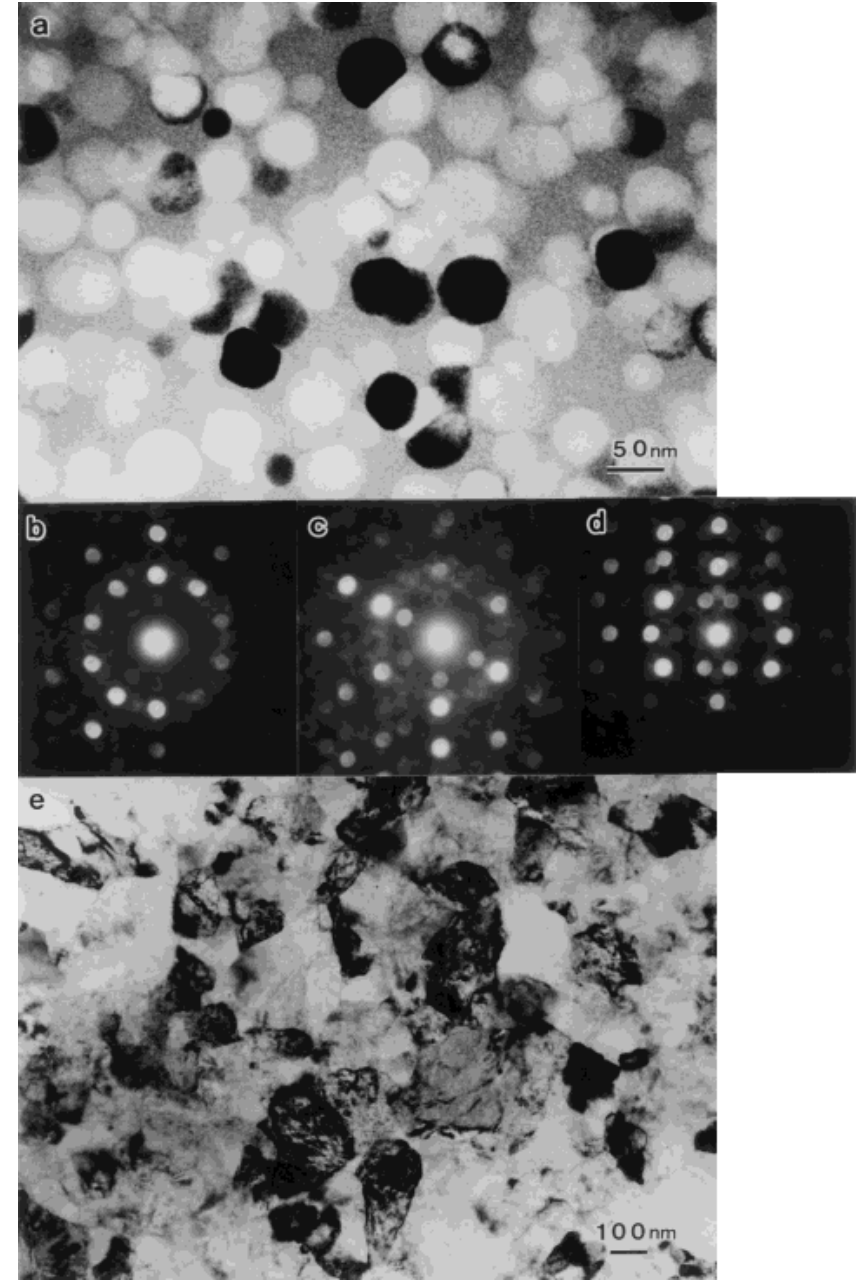

Fig. 17 Bright-field TEM image (a) and nanobeam electron diffraction patterns ((b) to (d)) of the $\mathrm{Zr}_{70} \mathrm{Cu}_{29} \mathrm{Pd}_{1}$ glassy alloy annealed for $120 \mathrm{~s}$ at $620 \mathrm{~K}$. The beam diameter for the nanobeam electron diffraction is $2.4 \mathrm{~nm}$. Bright-filed TEM image of the $\mathrm{Zr}_{70} \mathrm{Cu}_{30}$ glassy alloy annealed for $120 \mathrm{~s}$ at $655 \mathrm{~K}$ is also shown for comparison in (e).

$\mathrm{Pd}, \mathrm{Au}$ and $\mathrm{Pt})_{1}$ glassy alloys.

It has been also reported that the $\mathrm{Zr}-\mathrm{Ni}$ binary amorphous alloys are formed in a wide compositional range. However, no obvious glass transition is seen in the binary alloys. ${ }^{1)}$ We have compared the transformation behavior of $\mathrm{Zr}_{70} \mathrm{Ni}_{30}$ amorphous alloy substituting $\mathrm{Pd}, \mathrm{Au}$ and $\mathrm{Pt}$ for 1 at $\% \mathrm{Ni}$ with those in the $\mathrm{Zr}_{70} \mathrm{Cu}_{29}(\mathrm{Pd}, \mathrm{Au} \text { and } \mathrm{Pt})_{1}$ glassy alloys. Figure 18 shows DSC curves of the $\mathrm{Zr}_{70} \mathrm{Ni}_{30}$ and $\mathrm{Zr}_{70} \mathrm{Ni}_{29}(\mathrm{Pd}, \mathrm{Au} \text { and } \mathrm{Pt})_{1}$ amorphous alloys. Although the slight peak broadening and increase in the temperature of exothermic peak are seen in the noble metal-containing alloys as compared with the $\mathrm{Zr}_{70} \mathrm{Ni}_{30}$ amorphous alloy, all the curves have an only single exothermic peak without glass transition. The XRD patterns of the $\mathrm{Zr}_{70} \mathrm{Ni}_{30}$ and $\mathrm{Zr}_{70} \mathrm{Ni}_{29}(\mathrm{Pd}, \mathrm{Au} \text { and } \mathrm{Pt})_{1}$ amorphous alloys annealed for $120 \mathrm{~s}$ in the temperature range of 640 to $670 \mathrm{~K}$ (near $T_{\mathrm{x}}$ ) are shown in Fig. 19. All the alloys have a single tetragonal $\mathrm{Zr}_{2} \mathrm{Ni}$ phase as a primary crystallization phase. It is noticed that no fcc $\mathrm{Zr}_{2} \mathrm{Ni}$ and I-phases, which an icosahedral cluster is contained in their structures are observed in the $\mathrm{Zr}_{70} \mathrm{Ni}_{30}$ and $\mathrm{Zr}_{70} \mathrm{Ni}_{29}(\mathrm{Pd}, \mathrm{Au} \text { and } \mathrm{Pt})_{1}$ amorphous alloys.

Comparing the transformation behavior of the $\mathrm{Zr}_{70} \mathrm{Ni}_{29}$ $(\mathrm{Pd}, \mathrm{Au} \text { and } \mathrm{Pt})_{1}$ amorphous alloys with those of the $\mathrm{Zr}_{70} \mathrm{Cu}_{29}$

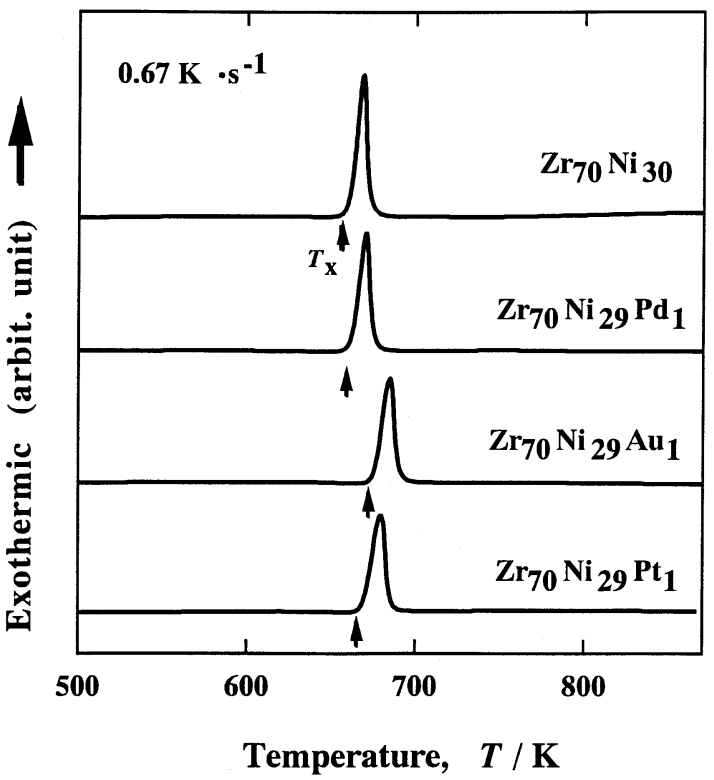

Fig. 18 DSC curves of the $\mathrm{Zr}_{70} \mathrm{Ni}_{30}$ and $\mathrm{Zr}_{70} \mathrm{Ni}_{29}(\mathrm{Pd}, \mathrm{Au} \text { and } \mathrm{Pt})_{1}$ amorphous alloys.

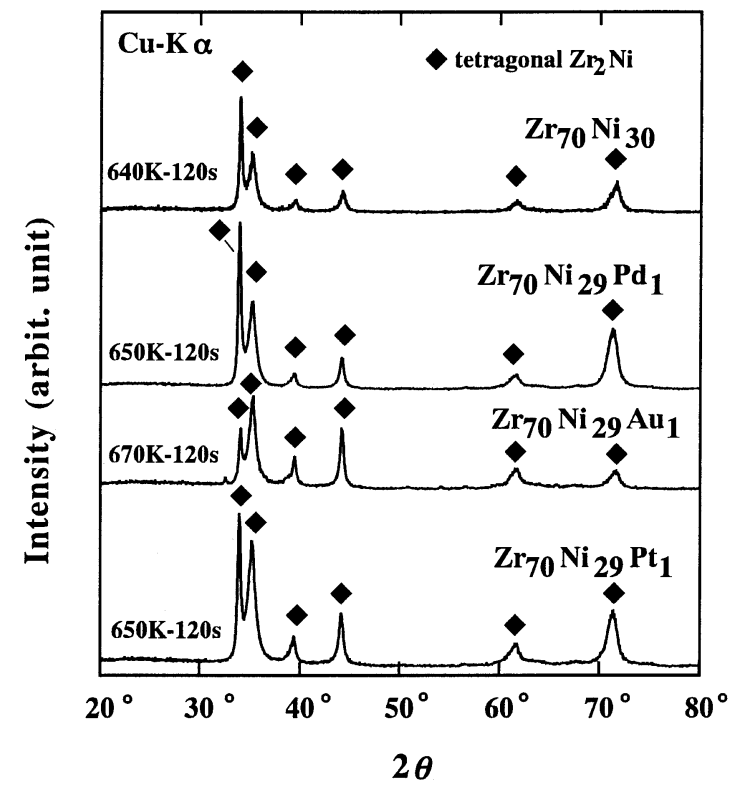

Fig. $19 \mathrm{X}$-ray diffraction patterns of the $\mathrm{Zr}_{70} \mathrm{Ni}_{30}$ and $\mathrm{Zr}_{70} \mathrm{Ni}_{29}(\mathrm{Pd}, \mathrm{Au}$ and $\mathrm{Pt})_{1}$ amorphous alloys annealed for $120 \mathrm{~s}$ in the temperature range of 640 to $670 \mathrm{~K}$.

$(\mathrm{Pd}, \mathrm{Au} \text { and } \mathrm{Pt})_{1}$ glassy alloys, we can realize the correlation between the appearance of the supercooled liquid state before crystallization and the formation of fcc $\mathrm{Zr}_{2} \mathrm{Ni}$ or I-phase as a primary phase. Therefore, it is concluded that the icosahedral short- or medium-range order exists in the $\mathrm{Zr}-\mathrm{Cu}$ binary glassy alloy and stabilizes the supercooled liquid state by retarding the atomic rearrangements for the formation of stable crystalline phase.

\section{Conclusions}

The factor for the stabilization of the supercooled liquid state in the Zr-based glassy alloys is investigated on the basis of the examination of transformation behavior from the glassy 
phase. It is found that the primary phase is the fcc $\mathrm{Zr}_{2} \mathrm{Ni}$ phase in the $\mathrm{Zr}_{65} \mathrm{Al}_{7.5} \mathrm{Ni}_{10} \mathrm{Cu}_{17.5}$ glassy alloy. With substituting $\mathrm{Ag}, \mathrm{Pd}, \mathrm{Au}$ or $\mathrm{Pt}$ for only $1 \mathrm{at} \% \mathrm{Cu}$, the primary phase changes to a mixture of fcc $\mathrm{Zr}_{2} \mathrm{Ni}$ and I-phases accompanying a broadening of crystallization reaction. The I-phase formation is confirmed by addition of the elements which have a weak or positive mixing enthalpy with one of the constitutional elements in $\mathrm{Zr}-\mathrm{Al}-\mathrm{Ni}-\mathrm{Cu}$ glassy alloys. Since the icosahedral phase is also precipitated by increasing $\mathrm{Zr}$ content substituted for a few at\% $\mathrm{Cu}$ in the $\mathrm{Zr}_{65} \mathrm{Al}_{7.5} \mathrm{Ni}_{10} \mathrm{Cu}_{17.5}$ glassy alloy, the important formation factor of the I-phase is attributed to an enhancement of nucleation from the glassy state by adding an appropriate element or slightly deviating the alloy composition from that with high GFA. It is realized that the slight deviation from the three component rules for high GFA is effective for the I-phase formation in the $\mathrm{Zr}-$ $\mathrm{Al}-\mathrm{Ni}-\mathrm{Cu}$ glassy alloy. Since the icosahedron is contained as a local structure in the unit cell in the fcc $\mathrm{Zr}_{2} \mathrm{Ni}$ and Iphases, we can propose the existence of the icosahedral shortor medium-range order in the $\mathrm{Zr}-\mathrm{Al}-\mathrm{Ni}-\mathrm{Cu}$ glassy alloy. The HREM image of the as-quenched $\mathrm{Zr}_{70} \mathrm{Al}_{7.5} \mathrm{Ni}_{10} \mathrm{Cu}_{12.5}$ glassy alloy contains local ordered regions which are suggested to be the icosahedral short- or medium-range order. The icosahedral order stabilizes the supercooled liquid state by suppressing the redistribution of constitutional elements to form the crystalline phase. The mechanism is concluded as a dominant factor for high GFA of the Zr-based glassy alloys. It is found that the I-phase is formed by substituting $\mathrm{Pd}, \mathrm{Au}$ or $\mathrm{Pt}$ for 1 at $\% \mathrm{Cu}$ in the $\mathrm{Zr}_{70} \mathrm{Cu}_{30}$ glassy alloy. Considering the appearance of the supercooled liquid region before crystallization in the $\mathrm{Zr}_{70} \mathrm{Cu}_{30}$ glassy alloy, we can point out the correlation between the I-phase formation and appearance of the supercooled liquid region. It is also concluded that the icosahedral short- or medium-range order is attributed to the stable supercooled liquid state and is formed by the existence of the $\mathrm{Zr}-\mathrm{Cu}$ atomic pair.

\section{Acknowledgements}

The authors thank Prof. E. Matsubara in IMR, Tohoku University and Dr. H. S. Chen in Bell Laboratories, Lucent technology for stimulating discussions.

\section{REFERENCES}

1) A. Inoue, T. Zhang and T. Masumoto: Mater. Trans., JIM 31 (1990) 177-183.

2) A. Inoue, T. Zhang and T. Masumoto: J. Non-Cryst. Solids 156-158 (1993) 473-480.

3) A. L. Peker and W. L. Johnson: Appl. Phys. Lett. 63 (1993) 2342-2344.

4) W. L. Johnson: MRS Bulletin 24 (1999) 42-56.

5) T. Zhang, A. Inoue and T. Masumoto: Mater. Trans., JIM 32 (1991) 1005-1010.

6) E. Matsubara, T. Tamura, Y. Waseda, A. Inoue, T. Zhang and T. Masumoto: Mater. Trans., JIM 33 (1992) 873-878.
7) M. Imafuku, S. Sato, H. Koshiba, E. Matsubara and A. Inoue: Mater. Trans., JIM 41 (2000) 1526-1529.

8) M. W. Chen, T. Zhang, A. Inoue, A. Sakai and T. Sakurai: Appl. Phys. Lett. 75 (1999) 1697-1699.

9) A. Inoue, T.Zhang, J. Saida, M. Matsushita, M. W. Chen and T. Sakurai: Mater. Trans., JIM 40 (1999) 1181-1184.

10) A. Inoue, T. Zhang, J. Saida and M. Matsushita: Mater. Trans., JIM 41 (2000) 1511-1520.

11) J. Saida and A. Inoue: J. Phys. Condens. Matter 13 (2001) L73-L78.

12) J. Saida and A. Inoue: Jpn. J. Appl. Phys. 40 (2001) L769-L772.

13) A. Inoue: Mater. Trans., JIM 36 (1995) 866-875.

14) A. Inoue, T. Zhang, M. W. Chen, T. Sakurai, J. Saida and M. Matsushita: J. Mater. Res. 15 (2000) 2195-2208.

15) L. Q. Xing, T. C. Hufnagel, J. Eckert, W. Löser and L. Schultz: Appl. Phys. Lett. 77 (2000) 1970-1972.

16) B. S. Murty, D. H. Ping, K. Hono and A. Inoue: Appl. Phys. Lett. 76 (2000) 55-57.

17) Z. Altounian, E. Batalla, J. O. Strom-Olsen and J. L. Walter: J. Appl. Phys. 61 (1987) 149-155.

18) F. R. de Bore, R. Boom, W. C. M. Mattens, A. R. Miedema and A. K. Niessen: Cohesion in Metals, (North-Holland, Amsterdam, 1988) p. $361-492$.

19) C. Li and A. Inoue: Phys. Rev. B 63 (2001) 1722011-1722014.

20) C. Li and A. Inoue: Mater. Lett. 50 (2001) 318-321.

21) C. Li and A. Inoue: J. Alloys Compd. 325 (2001) 230-235.

22) J. Saida and A. Inoue: unpublished research.

23) U. Köster, R. Janlewing and D. Zander: Proc. Int. Symp. Amo. Nanocryst. Mater., edited by A. Inoue, Jap. Soc. Prom. Sci., Akiu, Sendai, (2000) p. 69-79.

24) L. Q. Xing, J. Eckert, W. Löser and L. Schultz: Appl. Phys. Lett. 74 (1999) 664-666.

25) J. Saida, M. Matsushita and A. Inoue: Mater. Trans., JIM 41 (2000) 1505-1510.

26) J. Saida, M. Matsushita, C. Li and A. Inoue: Philos. Mag. Lett. 80 (2000) 737-743.

27) M. Matsushita, J. Saida, T. Zhang, A. Inoue, M. W. Chen and T. Sakurai: Philos. Mag. Lett. 80 (2000) 79-84.

28) U. Köster: Key Eng. Mater. 81-83 (1993) 647-662.

29) U. Köster, J. Meinhardt, S. Roos and R. Busch: Mater. Sci. Eng. A226228 (1997) 995-998.

30) Pearson's Handbook of Crystallographic Data for Intermetallic Phases, Vol. 3, edited by P. Villars and L. D. Calvert (ASM, 1991) p. 3421.

31) Z. Zhang and K. H. Kuo: Philos. Mag. B 54 (1986) L83-L87.

32) Q. B. Yang: Philos. Mag. Lett. 57 (1988) 171-176.

33) A. Inoue: Acta. Mater. 48 (2000) 277-304.

34) Y. Hirotsu, K. Anazawa and T. Okubo: Mater. Trans., JIM 31 (1990) 573-581.

35) B. S. Murty, D. H. Ping and K. Hono: Appl. Phys. Lett. 77 (2000) 1102 1104.

36) J. Saida, M. Matsushita, C. Li and A. Inoue: Philos. Mag. Lett. 81 (2001) 39-44.

37) J. Saida, M. Matsushita and A. Inoue: Appl. Phys. Lett. 79 (2001) 412 414.

38) For example, A. Inoue: Bulk Amorphous Alloys-Preparation and Fundamental Characteristics, (Trans Tech Publications, Zuerich, 1998) p. $1-10$.

39) A. Inoue, T. Zhang and T. Masumoto: J. Non-Cryst. Solids 150 (1992) 396-400.

40) M. Matsushita, J. Saida, C. Li and A. Inoue: J. Mater. Res. 15 (2000) 1280-1283.

41) B. S. Murty, D. H. Ping, K. Hono and A. Inoue: Scri. Mater. 43 (2000) 103-107.

42) C. Li and A. Inoue: Mater. Trans. 42 (2001) 1485-1488.

43) C. Li and A. Inoue: J. Phys. Condens. Matter 13 (2001) L803-L809. 